\title{
CONSUMPTION OF THYROID MEDICATIONS AS AN INDICATOR OF INCREASE OF THYROID MORBIDITY IN LATVIA FROM 2011 TO 2014
}

\author{
leva Kalere 1,2,\#, leva Strēle 1,2, Mārtiņš Miglinieks ${ }^{2}$, Ilze Repša ${ }^{3}$, Santa Pildava ${ }^{4}$, \\ Mihails Romanovs ${ }^{5}$, Valdis Pīrāgs ${ }^{2}$, and Ilze Konrāde ${ }^{1,6}$ \\ ${ }^{1}$ Rīga Stradiṇš University, 16 Dzirciema Str., Rīga, LV-1007, LATVIA \\ 2 University of Latvia, 19 Raina Blvd., Rīga, LV-1586, LATVIA \\ ${ }^{3}$ National Health Service, 31 Cēsu Str., Rīga, LATVIA \\ ${ }^{4}$ Centre for Disease Prevention and Control, 22 Duntes Str., Rīga, LATVIA \\ ${ }^{5}$ Residency Development Programme, University of Latvia, 19 Raiṇa Blvd., Rīga, LV-1586, LATVIA \\ ${ }^{6}$ Department of Endocrinology, Rīga East Clinical University Hospital, 2 Hipokrāta Str., Rīga, LV1038, LATVIA \\ \# Corresponding author, ieva.kalere@gmail.com
}

Contributed by Valdis Pīrāgs

\begin{abstract}
The most common autoimmune disorders with clinically opposite manifestations are hypothyroidism in Hashimoto's thyroiditis and hyperthyroidism in Graves' disease. The healthcare burden of thyroid disease is substantial, resulting in substantial health care costs. The aim of the present analysis is to assess the use of thyroid medications in Latvia from 2011 to 2014 by age and gender. Our study used reimbursed medication prescriptions data, collected by the National Health Service of Latvia. The main indicator was the number of prevalent users of thyroid medications each year from 2011 to 2014, stratified by age and gender. From 2011 to 2014, the number of thyroxine users per 100000 revealed a statistically significant increase in all age and gender groups, except in 0- to 9-year-old girls. The number of Thiamazole users among men increased in the age group from 40 to 89 years and in women age groups above 49 years. Increasing sales of both thyroid hormones and antithyroid medications are also observed in Estonia and Lithuania, indicating that growing thyroid morbidity is an issue in the whole region. The substantial increase in number of patients highlights the necessity for national guidelines on the use of thyroid function tests and standards of medical care.
\end{abstract}

Key words: Hyperthyroidism, hypothyroidism, Thiamazole, Levothyroxine, prescribing data.

+Thyroid disorders are common in European populations (Taylor et al., 2018). Thyroid dysfunction (hyperthyroidism or hypothyroidism) itself is associated with a higher risk of cardiovascular diseases, osteoporosis, and mental disorders (Carter et al., 2013; Leo et al., 2016). The pathogenic mechanisms of thyroid disorders are complex and many risk factors may contribute to dysfunction, but iodine deficiency is one of the main preventable causes of thyroid disorders. On the other hand, excessive iodine consumption can induce autoimmune thyroid diseases (AITD). The most common autoimmune disorders with clinically opposite manifestations are hypothyroidism in Hashimoto's thyroiditis (HT) and hyperthyroidism in Graves' disease. The health- care burden of thyroid disease is substantial, accounting for a large proportion of the workload in primary care and endocrinology practices, resulting in substantial health care costs (Kahaly et al., 2002; Møllehave et al., 2018). Despite the impact of thyroid disorders on public health and health care systems, the majority of countries do not regularly monitor thyroid morbidity. Previous reviews by Madariaga et al. (2014) and Taylor et al. (2018) were able to identify only 15 and 17 studies respectively, from European countries that quantified either the incidence or prevalence of thyroid dysfunction. In addition, consumption of thyroid medications can give an indirect measure of thyroid morbidity in the population. Sales figures, annually collected by 
CONSUMPTION OF THYROID MEDICATION IN LATVIA: DEFINED DAILY DOSES (DDD)* PER 1000 POPULATION PER DAY

\begin{tabular}{l|c|c|c|c|c|c|c|ccc}
\hline Year & 2009 & 2010 & 2011 & 2012 & 2013 & 2014 & 2015 & 2016 & 2017 \\
\hline Levothyroxine sodium & 8.84 & 8.75 & 9.56 & 10.59 & 11.87 & 12.89 & 13.19 & 14.25 \\
Thiamazole & 1.38 & 1.49 & 1.61 & 1.76 & 1.78 & 1.86 & 1.93 & 2.00 & 2.06
\end{tabular}

* 1 DDD corresponds to $0.15 \mathrm{mg}$ Levothyroxine sodium and $10 \mathrm{mg}$ Thiamazole. Anonymous, 2014; 2018b

the State Agency of Medicines of Latvia, show a steady increase in consumption of both antithyroid medication Thiamazole and the thyroid hormone Levothyroxine over the last nine years (Table 1), thereby indicating a growing health problem (Anonymous, 2014; 2018b). Still, the total sales of medicines do not show which population subgroups are most affected. Therefore, the aim of the present analysis was to assess the use of thyroid medications in Latvia from 2011 to 2014 by age and gender according to the reimbursed medication prescription data.

The study was based on the methodology developed during the EUthyroid project, which focused on prevention of iodine deficiency disorders in Europe. One of the project's cornerstones was a harmonised approach on monitoring of iodine status and thyroid morbidity among European countries. Our study used reimbursed medication prescriptions data, collected by the National Health Service (NHS) of Latvia. Both Levothyroxine and Thiamazole are reimbursed by state and dispensed prescriptions are recorded in the medications database by NHS. In accordance with the EUthyroid methodology, the main indicator was the number of prevalent users of thyroid medications in each separate calendar year from 2011 to 2014, stratified by age and gender. The user of thyroid medication was defined as an individual having at least one dispensed prescription of Levothyroxine sodium or Thiamazole (the Anatomic Therapeutic Chemical classification system codes H03AA01 and H03BB02, respectively) during the calendar year (Anonymous, 2017). Period prevalence of medication use per 100000 population was estimated. The trend over the fouryear period was assessed by the Chi-squared $\left({ }^{2}\right)$ test for trends. The average annual absolute increase in number of medication users was also estimated by simple linear regression.

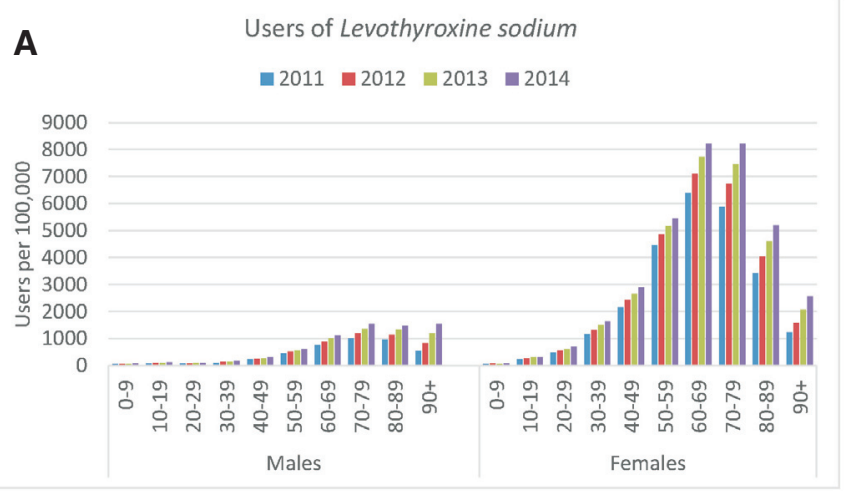

In comparison with the total sales of thyroid medications reported by the State Agency of Medicines, approximately $75-76 \%$ of Levothyroxine Sodium and $85-86 \%$ of Thiamazole were sold through the reimbursement system and recorded in the NHS Medications Database. The proportion of medication sales through the reimbursement system were stable over the studied period, suggesting the same pattern of choices of patient regarding medication purchases.

From 2011 to 2014 , in male population, number of thyroxine users per 100000 revealed a statistically significant increase in all age groups (Fig. 1A). The steepest increase was observed in the oldest age group (90 year old and above): the annual average increase in number of medication users was 337 individuals per 100000 (or $43 \%$ relative to the previous year). Still, younger age groups also experienced substantial increase in medication users; e.g., in men aged 60 to 89 years, the average annual increase ranged from 122 to 178 per 100000 (or $15-16 \%$ relative to the previous year). Among women, a statistically significant increase was observed in all age groups, except for 0 to 9 year old girls (Fig. 1A). Similarly, the highest relative increase (28\% per year on average) occurred among women 90 years old and older (on average, there were 447 medication users more every year per 100 000), whereas, in absolute terms, the highest increase of users was observed in 70-79- year-old women — 777 individuals per 100000 annually.

Among men, the number of Thiamazole users increased in the age group from 40 to 89 years (Fig. 1B). The highest increase in both relative and absolute terms was observed in 80-89-year-old men: on average, there were 48 more users each year per 100000 (or $11 \%$ relative to the previous year). In women, a statistically significant increase occurred in all age groups above 49 years (Fig. 1B). The steepest

\section{B}

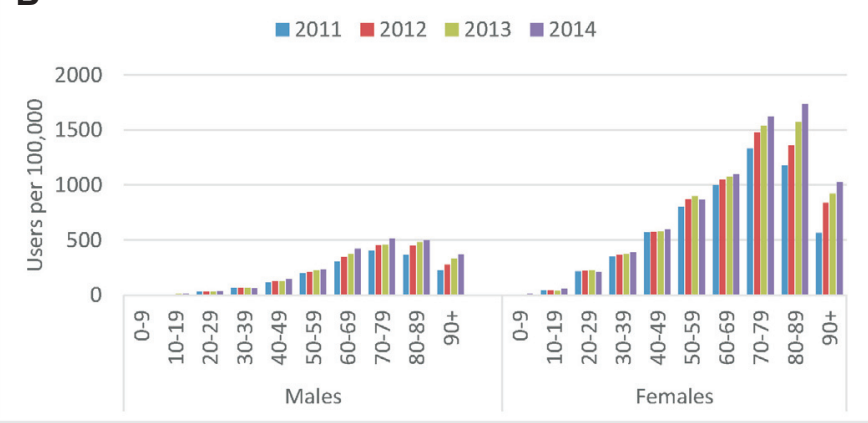

Fig. 1. A. Number of prevalent users of Levothyroxine sodium per 100000 population by gender, age group and calendar year; B number of prevalent users of Thiamazole sodium per 100000 population by gender, age group and calendar year. 
relative increase was among women aged 90 years and older was on average, $23 \%$ compared to the previous year; whereas in absolute measures, the highest increase of medication users was observed among 80-89 year old women; there were 188 more users of Thiamazole each year, on average, per 100000 .

Despite of the complete coverage of the population, NHS data may underrepresent health problems because of medications prescribed outside the reimbursement system. Due to the long waiting times to visit a specialist under the NHS, patients may choose to visit a private doctor and pay a full fee for their prescription. The share of out-of-pocket payments in endocrine care has not been formally assessed in Latvia, but the relatively low price of thyroid medications makes it probable. Therefore, the amount of thyroid medications sold through the reimbursement system and, thereby, recorded in the NHS data were compared with the sales figures from the Latvian State Agency of Medicines.

Interestingly, the most significant increase of Thyroxine users in men was seen in the oldest age group and men aged 60 to 89 years. A similar tendency was observed in females. Rise in thyroxine use among the elderly could be explained by a true increase of hypothyroidism at older age (Madariaga et al., 2014), or due to improved diagnostics. Thyroxine user prevalence was higher in the female group, compared to the male group, as in studies worldwide (Taylor et al., 2018). A similar tendency in thyroxine consumption was seen in Estonia and Lithuania (Rootslane et al., 2013; Seilis et al., 2016), indicating that growing thyroid morbidity is an issue in the whole region. Consumption of Thiamazole increased with age in both genders, similar to studies from Europe and the USA showing an increase in hyperthyroidism and antithyroid medication consumption with age (Hollowel et al., 2002; Madariaga et al., 2014), which is related to higher incidence of toxic goitre and increase in iodinerich medication use. Regarding gender-related use of Thiamazole, this study showed a similar male to female ratio, average $1: 4.5$, as in other studies (Hollowel et al., 2002; Vanderpump, 2011). The overall prevalence of thyroid medication users in this study showed numbers comparable to those found in Denmark (Møllehave et al., 2018). Data from Danish registries revealed that thyroid surgery and radioiodine treatment accounted for a negligible percentage of thyroid treatments (Møllehave et al., 2018). Therefore, it can be hypothesised that the increase in thyroid treatments is mostly due to autoimmune thyroid diseases, as these are predominantly treated medically. Another factor supporting this hypothesis is the increasing prevalence of other autoimmune diseases nationally. We do not have a system in place to detect AITD prevalence in Latvia. However, we have a diabetes registry, revealing an increase in type 1 diabetes prevalence per 100000 population from 198.6 in 2011 to 211.2 in 2014 (Anonymous, 2018a).

As mentioned above, iodine is an important player in thyroid pathology, but modern society experiences not just iodine deficiency, but also exposure to very high doses of iodine in radiographic iodinated contrast media (2.5-5.0 g of bioavailable free iodine per CT scan) or amiodarone (75 mg iodine per $200 \mathrm{mg}$ tablet), which are associated with a higher risk of thyroid dysfunction, including hyperthyroidism and hypothyroidism (Rhee et al., 2012).

Our results could also be explained by improved screening and diagnosis due to the availability and utilisation of TSH testing. We would like to emphasise that the measurement of serum TSH should be performed immediately at presentation for patients with atrial fibrillation, dyslipidaemia, osteoporosis and subfertility (Koutras, 1997; Pirich et al., 2000). The cumulative number of patients presenting with these conditions is quite considerable.

The funding allocated by the NHS for laboratory testing increased approximately 1.5 times over the analysed period (Anonymous, 2012; 2015). This enables healthcare professionals to refer their patients for testing and improves rates of detection of even subclinical AITDs. In recent years the European Thyroid Association has invested immense resources in the development of guidelines on management of subclinical hyperthyroidism and hypothyroidism, providing guidance for treatment in most clinical cases (Pearce et al., 2013; Bartalena et al., 2018). The substantial increase in patient numbers highlights the necessity for national guidelines on the use of thyroid function tests and standards of medical care.

\section{LIMITATIONS}

In real life clinical practice, it is possible to make mistakes in processing patient personal data when prescribing medications. Due to this, it would be desirable to use the more reliable criteria of two or more prescriptions per patient when using prescription data for analysis.

\section{ACKNOWLEDGEMENTS}

EU Horizon 2020 research and innovation programme under grant agreement No 634453; project EUthyroid. The authors thank the EUthyroid project leader Henry Völzke and the work package leader Betina H. Thuesen for designing, planning and managing the project and, in particular, morbidity data collection.

\section{REFERENCES}

Anonymous (2012). 20. Vēstis [20th Proceedings]. The National Health Service of the Republic of Latvia (in Latvian). Available from: http://www.vmnvd.gov.lv/lv/publikacijas/vestis (accessed 15.05.2019).

Anonymous (2014). Statistics On Medicines Consumption 2013. State Agency of Medicines. Available from: https://www.zva.gov.lv/sites/default/files/inline-files/zva-zstat-2013.pdf (accessed 15.05.2019).

Anonymous (2015). 23. Vēstis [23th Proceedings]. The National Health Service of the Republic of Latvia (in Latvian). Available from: http://www.vmnvd.gov.lv/lv/publikacijas/vestis (accessed 15.05.2019).

Anonymous (2017). Guidelines for ATC classification and DDD assignment 2018. WHO Collaborating Centre for Drug Statistics Methodology. Available from: https://www.whocc.no/filearchive/publications/guidelines.pdf (accessed 15.05.2019). 
Anonymous (2018a). Kopsavilkums par cukura diabēta pacientiem, 2001.-2017. [Summary about patients with diabetes mellitus, 2001.-2017.]. The Centre for Disease Prevention and Control (CDPC) of Latvia (in Latvian). Available from:

https://www.spkc.gov.lv/lv/statistika-un-petijumi/statistika/veselibas-apr upes-statistika1(accessed 15.05.2019).

Anonymous (2018b). Statistics On Medicines Consumption 2017. State Agency of Medicines. Available from: https://www.zva.gov.lv/sites/ deault/files/inline-files/zva-zstat-2013.pdf (accessed 15.05.2019).

Bartalena, L., Bogazzi, F., Chiovato, L., Hubalewska-Dydejczyk, A., Links, T., Vanderpump, M. (2018). 2018 European Thyroid Association (ETA) Guidelines for the Management of Amiodarone-Associated Thyroid Dysfunction. Eur. Thyroid J., 7 (2), 55-66.

Carter, Y., Sippel, R. S., Chen, H. (2013). Hypothyroidism after a cancer diagnosis: Etiology, diagnosis, complications, and management. The Oncologist, 19 (1), 34-43.

Hollowel, J. G., Staehling, N. W., Flanders, W. D., Hannon, W. H., Gunter, E. W., Spencer, C. A., Braverman, L. E. (2002). Serum TSH, T4, and thyroid antibodies in the United States population (1988 to 1994): National Health and Nutrition Examination Survey (NHANES III). J. Clin. Endocrinol. Metab., 87 (2), 489-499.

Kahaly, G. J., Dietlein, M. (2002). Cost estimation of thyroid disorders in Germany. Thyroid, 12 (10), 909-914.

Koutras, D. A. (1997). Disturbances of menstruation in thyroid disease. Ann. New York Acad. Sci., 816 (1), 280-284.

Leo, S. D., Lee, S. Y., Braverman, L. E. (2016). Hyperthyroidism. The Lancet, 388 (10047), 906-918.

Received 3 January 2019

Accepted in the final form 24 May 2019
Madariaga, A. G., Palacios, S. S., Guillén-Grima, F., Galofré, J. C. (2014). The incidence and prevalence of thyroid dysfunction in Europe: A meta-analysis. J. Clin. Endocrinol. Metab., 99 (3), 923-931.

Møllehave, L., Linneberg, A., Skaaby, T., Knudsen, N., Ehlers, L., Jørgensen, T., Thuesen, B. (2018). Trends in costs of thyroid disease treatment in Denmark during 1995-2015. Eur. Thyroid J., 7 (2), 75-83.

Pearce, S. H., Brabant, G., Duntas, L. H., Monzani, F., Peeters, R. P., Razvi, S., Wemeau, J. (2013). 2013 ETA Guideline: Management of Subclinical Hypothyroidism. Eur. Thyroid J., 2 (4), 215-228

Pirich, C., Müllner, M., Sinzinger, H. (2000). Prevalence and relevance of thyroid dysfunction in 1922 cholesterol screening participants. J. Clin. Epidemiol., 53 (6), 623-629.

Rhee, C. M., Bhan, I., Alexander, E. K., Brunelli, S. M. (2012). Association between iodinated contrast media exposure and incident hyperthyroidism and hypothyroidism. Arch. Int. Med., 172 (2), 153.

Rootslane L., Laius O., Sepp J., Kurvits K., Seilis A., Gailīte E., Kikute D., Dr Gulbinovič J., Tomaševič R., Stasevičiūtė V. (2013). Baltic Statistics On Medicine 2010-2012. Estonian State Agency Of Medicines. Available from: http://www.ravimiamet.ee/sites/default/files/documents/publications/baltic_statistics_on_medicines_2010_2012/files/mobile/index.html \#4 (accessed 15.05.2019).

Seilis A., Gailīte E., Rootslane L., Laius O., Savaikis L., Tomaševič R. (2016). Baltic Statistics On Medicine 2013-2015. Estonian State Agency Of Medicines. Available from: https:/www.zva.gov.lv/sites/default/ files/2017-12/Baltic\%20Statistics\%20on\%20Medicines\%202013\%20 -\%202015.pdf (accessed 15.05.2019).

Taylor, P. N., Albrecht, D., Scholz, A., Gutierrez-Buey, G., Lazarus, J. H., Dayan, C. M., Okosieme, O. E. (2018). Global epidemiology of hyperthyroidism and hypothyroidism. Nature Rev. Endocrinol., 14 (5), 301-316.

Vanderpump, M. P. (2011). The epidemiology of thyroid disease. Brit. Med. Bull., 99 (1), 39-51.

\section{VAIROGDZIEDZERA MEDIKAMENTU PATĒRIN̦Š KĀ VAIROGDZIEDZERA SLIMĪBU PIEAUGUMA RĀDĪTĀJS LATVIJĀ NO 2011. GADA LİDZ 2014. GADAM}

Visbiežāk sastopamās vairogdziedzera autoimūnās slimības ar klīniski pretējām izpausmēm ir hipotireoze Hašimoto tireoidīta un hipertireoze Greivsa slimības gadījumā. Vairogdziedzera slimību veselības aprūpes slogs ir ievērojams, un tas rada būtiskas veselības aprūpes izmaksas. Šìs analīzes mērkis ir izvērtēt vairogdziedzera medikamentu lietošanu Latvijā no 2011. līdz 2014. gadam pēc pacientu vecuma un dzimuma. Šajā pētījumā izmantoti kompensēto zāḷu recepšu dati, ko apkopojis Latvijas Nacionālais veselības dienests. Galvenais rādītājs bija vairogdziedzera medikamentu lietotāju skaits katrā gadā no 2011. līdz 2014. gadam, stratificējot pēc vecuma un dzimuma. No 2011. līdz 2014. gadam tiroksīna lietotāju skaits uz 100000 statistiski nozīmīgi pieauga visās vecuma un dzimuma grupās, izņemot 0 līdz 9 gadus vecas meitenes. Tiamazola lietotāju skaits vīriešu vidū pieaudzis vecuma grupā no 40 līdz 89 gadiem un sieviešu vecuma grupā virs 49 gadiem. Arvien pieaugoši gan vairogdziedzera hormonu, gan tireostatisko medikamentu pārdošanas apjomi tiek novēroti arī Igaunijā un Lietuvā, kas norāda, ka pieaugošs pacientu skaits ar vairogdziedzera slimībām ir problēma visā reğionā. Ievērojamais pacientu skaita pieaugums akcentē nepieciešamību pēc Nacionālām rekomendācijām par vairogdziedzera funkcionālo testu un medicīniskās aprūpes standartu mērḳtiecīgu izmantošanu. 